\title{
A Novel Anionic-phosphate-platinum Complex Effectively Targets a Cisplatinum-resistant Osteosarcoma in a Patient-derived Orthotopic Xenograft Mouse Model
}

\author{
KENTARO IGARASHI ${ }^{1,2,3}$, KEI KAWAGUCHI ${ }^{1,2}$, NORIO YAMAMOTO ${ }^{3}$, KATSUHIRO HAYASHI $^{3}$, \\ HIROAKI KIMURA ${ }^{3}$, SHINJI MIWA3, TAKASHI HIGUCHI ${ }^{3}$, YUTA TANIGUCHI ${ }^{3}$, HIROTAKA YONEZAWA $^{3}$, \\ YOSHIHIRO ARAKI ${ }^{3}$, SEI MORINAGA ${ }^{3}$, SWETA MISRA ${ }^{4}$, SCOTT D. NELSON ${ }^{5}$, SARAH M. DRY ${ }^{5}$, YUNFENG LI ${ }^{5}$, \\ AKIRA ODANI ${ }^{6}$, SHREE RAM SINGH ${ }^{7}$, HIROYUKI TSUCHIYA $^{3}$ and ROBERT M. HOFFMAN ${ }^{1,2}$ \\ ${ }^{1}$ AntiCancer, Inc., San Diego, CA, U.S.A.; \\ ${ }^{2}$ Department of Surgery, University of California, San Diego, CA, U.S.A.; \\ ${ }^{3}$ Department of Orthopaedic Surgery, Kanazawa University, Kanazawa, Japan; \\ ${ }^{4}$ Mouse Cancer Genetics Program, National Cancer Institute, Frederick, MD, U.S.A.; \\ ${ }^{5}$ Department of Pathology, University of California, Los Angeles, CA, U.S.A.; \\ ${ }^{6}$ Division of Pharmaceutical Sciences, Kanazawa University, Kanazawa, Japan; \\ ${ }^{7}$ Basic Research Laboratory, National Cancer Institute, Frederick, MD, U.S.A.
}

\begin{abstract}
Background/Aim: We have previously developed a novel bone-targeting platinum compound, $3 P t$, and showed that it has strong inhibitory activity against osteosarcoma cells and orthotopic cell-line xenograft mouse models. In the present report, we compared the efficacy of $3 P t$ to cisplatinum $(C D D P)$ in a CDDP-resistant relapsed osteosarcoma patient-derived orthotopic xenograft (PDOX) mouse model. Patients and Methods: The tumor of a patient with osteosarcoma of the distal femur was treated with CDDP-based chemotherapy followed by surgery. The surgical specimen was used to establish a PDOX model. An osteosarcoma cell line was also established from the original patient tumor. Osteosarcoma cell viability was assessed with the WST-8 assay and the IC50 values were calculated. The PDOX models were randomized into three groups: untreated
\end{abstract}

This article is freely accessible online.

Correspondence to: Robert M. Hoffman, Ph.D., AntiCancer, Inc., 7917 Ostrow Street, San Diego, CA 92111, U.S.A. Tel: +1 8586542555, e-mail: all@anticancer.com; Shree Ram Singh, Ph.D., Basic Research Laboratory, National Cancer Institute, Frederick, MD, U.S.A. Tel: +1 3018467331, e-mail: singhshr@mail.nih.gov; Hiroyuki Tsuchiya, MD, Ph.D., Department of Orthopaedic Surgery, Graduate School of Medicine, Kanazawa University, 13-1 Takaramachi, Kanazawa 920-8641, Japan. Tel: +81 0762652374, e-mail: tsuchi@med.kanazawa-u.ac.jp

Key Words: Osteosarcoma, cisplatinum-resistant, platinum complex, efficacy, 3Pt, PDOX. control, CDDP-treated group, and 3Pt-treated group. Tumor size and body weight were measured twice a week. Results: 3 Pt had a strong concentration-dependent cytocidal effect in vitro. The $I_{50}$ value of $3 P t$ was significantly lower than that of CDDP. On day 14 of the treatment, 3Pt caused a significantly greater tumor growth inhibition compared to the untreated control and CDDP-treated mice. Conclusion: $3 P t$ is a promising clinical candidate for the treatment of recalcitrant osteosarcoma.

Osteosarcoma is a rare and highly malignant mesenchymal bone tumor. The primary tumor is pathologically characterized by the formation of immature bone or osteoid. A bimodal distribution of osteosarcoma occurence has been reported, with a first peak in adolescence and a second peak in older age (1). Patients with osteosarcoma treated with chemotherapy and surgery have approximately a 70\% 5-year survival rate (2-4).

First-line chemotherapy for osteosarcoma includes highdose methotrexate (MTX), cisplatinum (CDDP), doxorubicin, (DCX) and ifosfamide (IFS) (5-9). However, dose escalation of these drugs has not been effective for recalcitrant osteosarcoma (6), with 5-year overall survival rates being less than $20 \%$ (6-9).

We have previously developed a novel platinum complex 3Pt ([Pt(Pt (1R,2R-diaminocyclohexane)(myo-inositol-1,2,3, 4,5,6-hexakisphosphate))2]), which comprises anionic phosphate moieties (10). The cytotoxic potency of 3Pt was higher than that of CDDP in all osteosarcoma cell lines tested. 3Pt was also effective in CDDP-resistant cells (10). Mice treated with $3 \mathrm{Pt}$ showed no renal cell injury compared 
to mice treated with CDDP, which developed renal cell apoptosis (11). 3Pt targets bone hydroxyapatite and contains germinal bisphosphonate moieties for drug delivery (11). Kasahara et al. (11) have measured bone Pt (platinum) concentration and found that $3 \mathrm{Pt}$ peaked at $24 \mathrm{~h}$. The mean Pt value was 2.5 -fold higher compared to the CDDP. They have also reported that $3 \mathrm{Pt}$ decreased the volume of bone resorption compared to CDDP in a bone invasion model using the head and neck cancer cell line, OSC-19 (11).

Our laboratory has developed the patient-derived orthotopic xenograft (PDOX) nude mouse model for all major cancers (12) and we have previously reported that $3 \mathrm{Pt}$ was more effective than CDDP against an undifferentiated pleomorphic soft-tissue sarcoma (UPS) PDOX mouse model (13).

In the present study, we determined the efficacy of $3 \mathrm{Pt}$ against a CDDP-resistant relapsed osteosarcoma PDOX model in comparison to CDDP.

\section{Materials and Methods}

Mice. Athymic nu/nu nude mice (AntiCancer Inc., San Diego, CA, USA), 4-6 weeks old, were used (14-20). All animal studies were conducted according to an AntiCancer Inc. Institutional Animal Care and Use Committee (IACUC) protocol specifically approved for this study and in accordance with the principles and procedures outlined in the National Institutes of Health Guide for the Care and Use of Animals under Assurance Number A3873-1 (14-20). In order to minimize any suffering of the animals, anesthesia and analgesics were used for all surgical experiments as previously described (14-20). Procedures for mouse housing, handling, anesthesia, feeding, and humane endpoint criteria have been previously described (14-20).

Patient-derived tumor. The study was reviewed and approved by the UCLA Institutional Review Board (IRB \#10-001857) before it began. Written informed consent was obtained from the patient as part of the above-mentioned UCLA Institutional Review Boardapproved protocol. A 16-year old patient with localized left distal femoral high-grade osteosarcoma underwent CDDP based neoadjuvant chemotherapy and limb-salvage distal-femoral replacement. The tumor necrosis rate of the primary tumor after CDDP-based chemotherapy was $70 \%$. One year later, the osteosarcoma relapsed and three bilateral metachronous pulmonary metastases appeared. The patient was treated with curative-intent surgery at the Division of Surgical Oncology, University of California, Los Angeles (UCLA). The patient did not receive chemotherapy or radiotherapy prior to lung surgery (21).

Establishment of PDOX model. A fresh surgical specimen of the patient's lung metastases was previously obtained and transported immediately to the laboratory at AntiCancer, Inc., on wet ice. The procedures for tumor tissue fragmentation and its subcutaneous implantation in nude mice have been reported (22). The subcutaneously-implanted patient derived xenograft was grown and established 3 weeks later in mice. The grown tumors were cut into small fragments (3-4 mm). Nude mice were anesthetized, and a 10 $\mathrm{mm}$ skin incision was made on the right thigh. Then vastus lateralis muscle and biceps femoris muscle were split to reach distal femur.
An incision was made in the lateral patello-femoral ligament, and the knee joint was spared. Then the lateral condyle of the femur was resected. A single 3 to $4 \mathrm{~mm}$ tumor fragment was implanted orthotopically into the space to establish a PDOX model. The muscle and wound were closed as described before (22).

Primary culture of patient-derived tumor. After the osteosarcoma PDOX was grown and established in nude mice, the grown tumors were harvested and cut into small fragments (1 mm or less). These fragments were placed in a $25 \mathrm{~cm}^{2}$ sterile flask containing RPMI1640 supplemented with $10 \%$ fetal boven serum (FBS). Next day, the cell culture was rinsed twice with PBS to remove nonadherent cells and excess tissue. The medium was changed every 34 days thereafter (23).

Growth inhibition assay. Viability of the patient-derived osteosarcoma cell line (AC-OS01) was assessed with the WST-8 dye reduction assay. Cells were seeded in 96-well flat-bottomed microplates $(100 \mu \mathrm{l} /$ well $)$ at $5 \times 10^{4}$ cells $/ \mathrm{ml}$, incubated at $37^{\circ} \mathrm{C}$ for $24 \mathrm{~h}$, and exposed to various concentrations of the tested compounds for $72 \mathrm{~h}$. For each concentration, at least 8 wells were used. After incubation with the tested compounds, $10 \mu \mathrm{l}$ WST- 8 solution were added to each well followed by further incubation for $3 \mathrm{~h}$ at $37^{\circ} \mathrm{C}$. Absorption was measured using a microprocessor-controlled microplate reader (Sunrise $^{\mathrm{TM}}$; TECAN, San Jose, CA, USA) at $450 \mathrm{~nm}$. Cell-survival fractions were calculated as the percentage of untreated control cells. $\mathrm{IC}_{50}$ values were derived from concentration-response curves (21).

Treatment design in the PDOX model of CDDP-resistant relapsed osteosarcoma. The PDOX models were randomized into the following groups when tumor volume reached $100 \mathrm{~mm}^{3}$ : G1, (untreated control, $\mathrm{n}=8)$; G2, (CDDP $6 \mathrm{mg} / \mathrm{kg}(15 \mu \mathrm{mol} / \mathrm{kg})$, intraperitoneal (i.p.) injection, weekly, for 2 weeks, n=8); G3, 3Pt (41.1 mg/kg (15 $\mu \mathrm{mol} / \mathrm{kg})$, i.p. injection, weekly, for 2 weeks) (10) (Figure 1). Tumor length, width and mouse body weight were measured twice a week with calipers. Tumor volume was calculated with the following formula: Tumor volume $\left(\mathrm{mm}^{3}\right)=$ length $(\mathrm{mm}) \times$ width $(\mathrm{mm}) \times$ width $(\mathrm{mm}) \times 1 / 2$. Data are presented as mean \pm SD .

Histological examination. Fresh tumor samples were fixed in $10 \%$ formalin and embedded in paraffin before sectioning and staining. Tissue sections $(3 \mu \mathrm{m})$ were deparaffinized in xylene and rehydrated in an ethanol series. Hematoxylin and eosin (H\&E) staining was performed according to standard protocols. Histological examination was performed as previously described (14).

Statistical analysis. Data are presented as mean \pm SD and groups were compared using the unpaired Student's $t$-test (13). A $p$-value of 0.05 or less indicates statistically significant differences.

\section{Results}

Efficacy of CDDP and 3Pt on a patient-derived osteosarcoma cell line. The cytotoxic activity of CDDP and 3Pt was determined on the patient-derived osteosarcoma cell line (ACOS01). Cells were incubated for $72 \mathrm{~h}$ with each compound and their survival was evaluated as described in the Materials and Methods Section. CDDP and 3Pt significantly inhibited growth of AC-OS01 cells in a dose-dependent manner (Figure 


\section{CDDP}
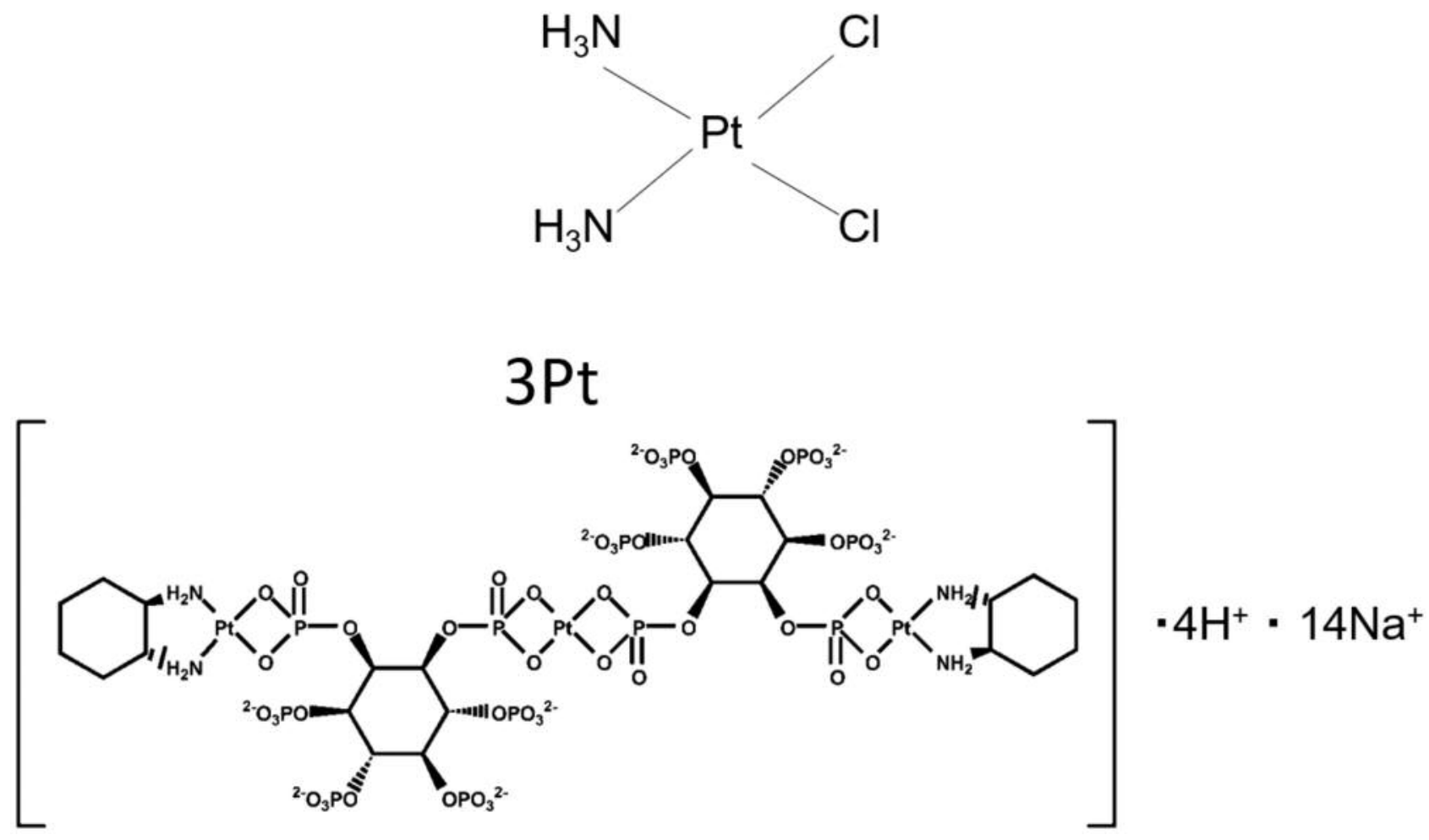

Figure 1. Structure of CDDP and $3 P t(10)$.

$1 \mathrm{~B}$ and $\mathrm{C}$, and Figure 2). The $\mathrm{IC}_{50}$ of $\mathrm{CDDP}$ was $4.74 \pm 0.98$ $\mu \mathrm{M}$ and $3 \mathrm{Pt}$ for AC-OS01 was $0.41 \pm 0.07 \mu \mathrm{M}$ (Table I).

Effect of CDDP and 3Pt on a CDDP-resistant osteosarcoma PDOX mouse model. On day 14 of treatment, 3Pt significantly inhibited tumor growth compared to the untreated control: control (G1): $824.6 \pm 250.9 \mathrm{~mm}^{3}$; CDDP (G2): $583.5 \pm 169.8 \mathrm{~mm}^{3}$; 3Pt. (G3): $234.7 \pm 75.1 \mathrm{~mm}^{3}$, (CDDP: $p=0.07$; 3Pt: $p=0.0001)$. 3Pt was significantly more effective than CDDP ( $p=0.0003$ ) (Figure 3A and B). There were no animal deaths, limb necrosis or paraplegia in any group. The body weight of the treated mice was not significantly different between any group (Figure 4).

Histology of original tumor and implanted tumors. High power photomicrographs of the untreated PDOX tumor showed a neoplastic chondroid matrix occupied by anaplastic cells. The tumor had hypercellular areas populated by anaplastic cells displaying nuclear pleomorphism, coarse and hyperchromatic chromatin and abundant mitotic figures (Figure 5A). PDOX tumors treated with CDDP comprised viable cells without apparent necrosis or inflammatory changes and almost the
Table I. IC 50 value of cisplatin and 3Pt against AC-OSO1 cells.

\begin{tabular}{lcc}
\hline \multicolumn{3}{c}{$\mathrm{IC}_{50}(\mu \mathrm{M})$} \\
\cline { 2 - 3 } & $\mathrm{CDDP}$ & $3 \mathrm{Pt}$ \\
\hline AC-OS-01 & $4.74 \pm 0.98$ & $0.41 \pm 0.07$ \\
\hline
\end{tabular}

same features compared to the untreated control (Figure 5B). PDOX tumor treated with $3 \mathrm{Pt}$ showed changes in cancer-cell shape with necrosis (Figure 5C).

\section{Discussion}

In the present study, the bone-targeting platinum complex, $3 \mathrm{Pt}$, inhibited tumor growth in an osteosarcoma PDOX model significantly better than CDDP.

An anionic platinum complex containing bisphosphonates, $3 \mathrm{Pt}$, was developed to achieve high accumulation in the bone. 3Pt may be an effective drug for the treatment of other bone cancers and metastases in addition to osteosarcoma, 

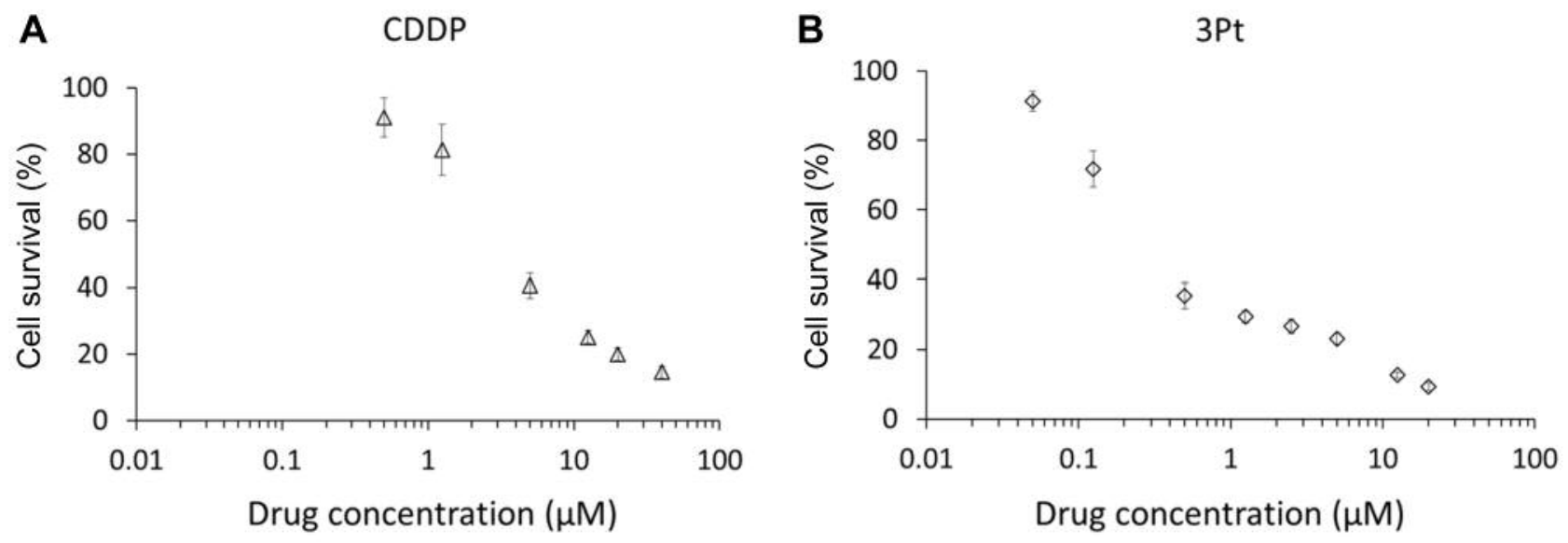

Figure 2. Growth-inhibition assay. Growth-inhibition of patient-derived osteosarcoma AC-OSO1 calls treated with CDDP (A) or 3Pt (B). Cells were incubated with each drug for $72 \mathrm{~h}$ and then growth was assessed with the WST-8 method.
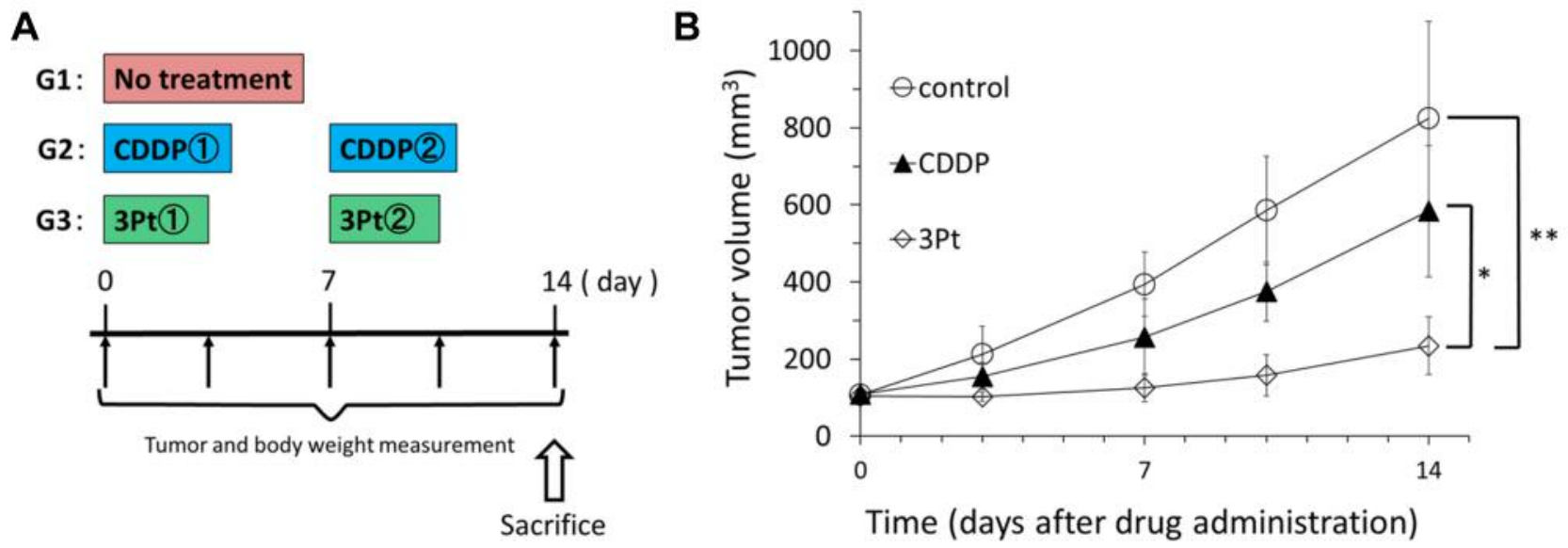

Figure 3. In vivo antitumor efficacy of CDDP and 3Pt on osteosarcoma PDOX mouse model. (A) Treatment protocol (B) Osteosarcoma was grown orthotopically in the right distal femur of nude mice and allowed to form tumors. Mice were treated with CDDP, 3Pt. [CDDP (20 umol/kg=6 $\mathrm{mg} / \mathrm{kg} /$ week i.p. for 2 weeks], or 3 Pt $(15 \mu \mathrm{mol} / \mathrm{kg}=41.1 \mathrm{mg} / \mathrm{kg} /$ week i.p. for 2 weeks). Tumor volume was measured at the indicated time points after the onset of treatment. $N=8$ mice/group. ${ }^{*} p=0.0004, * * p=0.0002$.

since the PO3 moiety of this complex has high affinity for the bone (10). A previous report has shown that $\mathrm{Pt}$ concentration in the bone was higher with $3 \mathrm{Pt}$ than with CDDP, with a peak at $24 \mathrm{~h}$ (11). The greater accumulation of $3 \mathrm{Pt}$ in the bone may be responsible for its increased effectiveness.

Nephrotoxicity is one of the most significant adverse effects of CDDP (24), which limits its dose and efficacy in cancer patients. 3Pt has increased solubility in order to avoid platinum nephrotoxicity. A previous report has shown that the number of apoptotic renal cells in 3Pt-treated mice was significantly lower than that in CDDP-treated mice (11). 3Pt showed excellent aqueous solution solubility (25). Furthermore, the absorption of $3 \mathrm{Pt}$ in the bone may serve as a buffer and reduce accumulation in the kidney, which may be one factor that reduces renal injury (24).

The present study showed that the safety and antitumor efficacy of 3Pt was superior to that of CDDP in a CDDPresistant osteosarcoma PDOX model. PDOX models (12, 2628) have important advantages over subcutaneous models (29) in that the tumors are growing in the proper microenvironment as in the present case in the bone. 

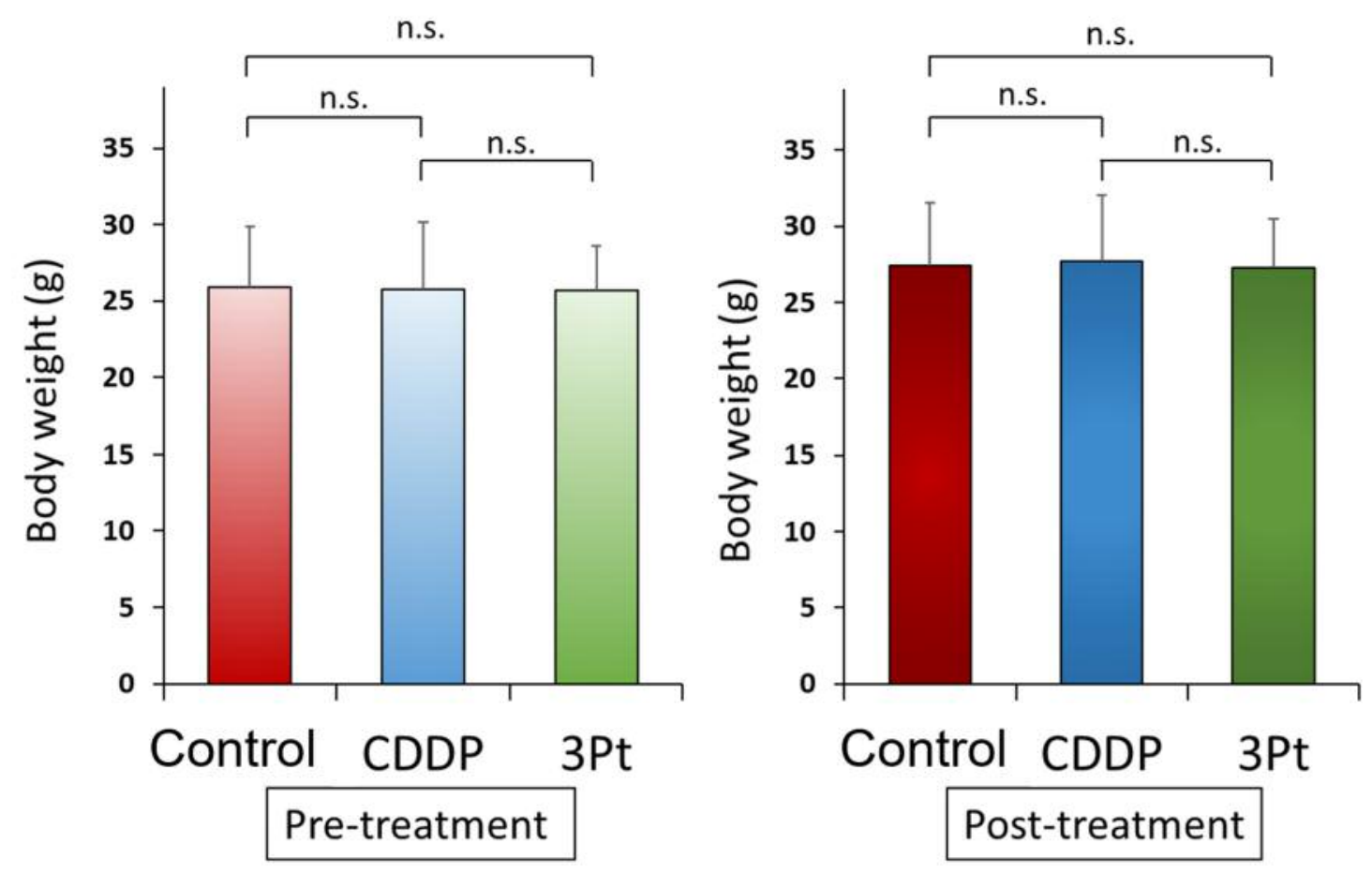

Figure 4. Body weight. Bar graphs show body weight in each group at pre-treatment and 2 weeks after initiation of drug administration. There were no significant differences between any group. n.s.: no significant difference.
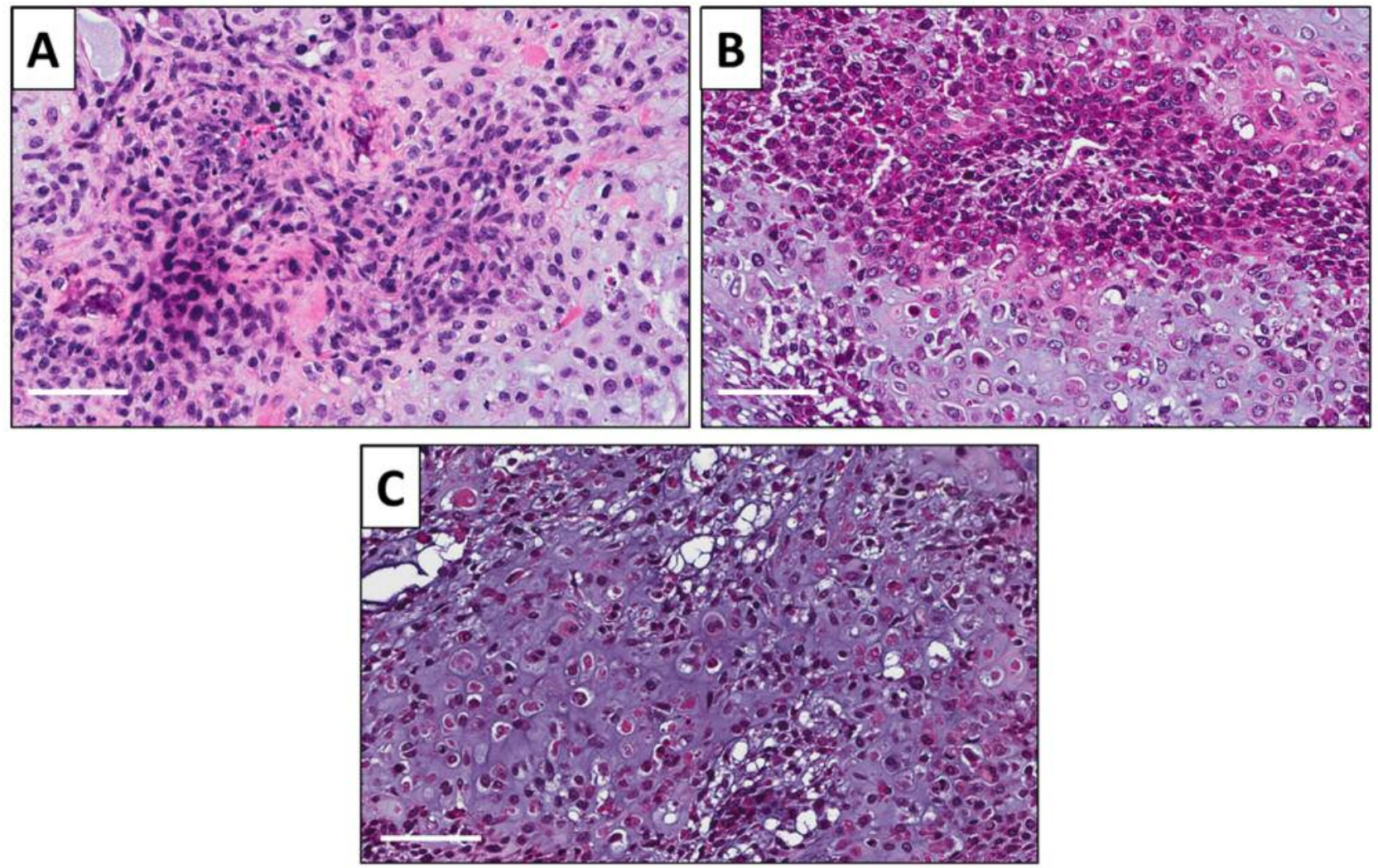

Figure 5. Tumor histology. $H \&$ E-stained sections of the untreated PDOX tumor (A), PDOX tumor treated with CDDP (B), PDOX tumor treated with $3 \mathrm{Pt}(\mathrm{C})$. White scale bars: $80 \mu \mathrm{m}$. 


\section{Conflicts of Interest}

KI, KK, NY, KH, HK, SM, TH and RMH are or were unsalaried members of AntiCancer Inc. which uses PDOX models for contract research. There are no other competing financial interests.

\section{Authors' Contributions}

Conception and design: KI and RMH. Acquisition of data: KI, KK, NY, KH, HK, SM, TH, YT, HY, YK, and SM. Analysis and interpretation of data: KI, KK, NY, KH, HK, SM, TH, YT, HY, YK, SM, SDN, SMD, YL, AO, SRS, HT and RMH. Writing, review, and/or revision of the manuscript: KI, RMH, and SRS.

\section{Acknowledgements}

This paper is dedicated to the memory of AR Moossa, MD, Sun Lee, MD, Professor Li Jia Xi, and Masaki Kitajima, MD.

\section{References}

1 Ottaviani G and Jaffe N: The epidemiology of osteosarcoma. Cancer Treat Res 152: 3-13, 2009. PMID: 20213383. DOI: 10.1007/978-1-4419-0284-9_1

2 Bacci G, Ferrari S, Lari S, Mercuri M, Donati D, Longhi A, Forni C, Bertoni F, Versari M and Pignotti E: Osteosarcoma of the limb. Amputation or limb salvage in patients treated by neoadjuvant chemotherapy. J Bone Joint Surg Br 84(1): 88-92, 2002. PMID: 11837839. DOI: 10.1302/0301-620x.84b1.12211

3 Muscolo DL, Ayerza MA, Aponte-Tinao LA and Ranalletta M: Partial epiphyseal preservation and intercalary allograft reconstruction in high-grade metaphyseal osteosarcoma of the knee. J Bone Joint Surg Am 87: 226-236, 2005. PMID: 16140796. DOI: $10.2106 / J B J S . E .00253$

4 Simon MA, Aschliman MA, Thomas N and Mankin HJ: Limbsalvage treatment versus amputation for osteosarcoma of the distal end of the femur. J Bone Joint Surg Am 68(9): 1331-1337, 1986. PMID: 3465732.

5 Saeter G, Alvegård TA, Elomaa I, Stenwig AE, Holmström T and Solheim OP: Treatment of osteosarcoma of the extremities with the T-10 protocol, with emphasis on the effects of preoperative chemotherapy with single-agent high-dose methotrexate: a Scandinavian Sarcoma Group study. J Clin Oncol 9(10): 17661775, 1991. PMID: 1717666. DOI: 10.1200/JCO.1991.9.10.1766

6 Lewis VO: What's new in musculoskeletal oncology, J Bone Joint Surg Am 91(6): 1546-1556, 2009. PMID: 19487537. DOI: 10.2106/JBJS.I.00375

7 Meyers PA, Gorlick R, Heller G, Casper E, Lane J, Huvos AG and Healey JH: Intensification of preoperative chemotherapy for osteogenic sarcoma: results of the Memorial Sloan-Kettering (T12) protocol. J Clin Oncol 16(7): 2452-2458, 1998. PMID: 9667263. DOI: $10.1200 / J C O .1998 .16 .7 .2452$

8 Fuchs N, Bielack SS, Epler D, Bieling P, Delling G, Körholz D, Graf N, Heise U, Jürgens H, Kotz R, Salzer-Kuntschik M, Weinel P, Werner M and Winkler K: Long-term results of the cooperative German-Austrian-Swiss osteosarcoma study group's protocol COSS-86 of intensive multidrug chemotherapy and surgery for osteosarcoma of the limbs. Ann Oncol 9(8): 893-899, 1998. PMID: 9789613 . DOI: 10.1023/a:1008391103132
9 Bacci G, Briccoli A, Ferrari S, Longhi A, Mercuri M, Capanna R, Donati D, Lari S, Forni C and DePaolis M: Neoadjuvant chemotherapy for osteosarcoma of the extremity: long-term results of the Rizzoli's 4th protocol. Eur J Cancer 37(16): 2030-2039, 2001. PMID: 11597381. DOI: 10.1016/s0959-8049(01)00229-5

10 Igarashi K, Yamamoto N, Hayashi K, Takeuchi A, Miwa S, Odani A and Tsuchiya H: Effectiveness of two novel anionic and cationic platinum complexes in the treatment of osteosarcoma. Anticancer Agents Med Chem 15(3): 390-399, 2015. PMID: 25511510. DOI: $10.2174 / 1871520615666141216151547$

11 Kasahara Y, Endo K, Ueno T, Ueno H, Moriyama-Kita M, Odani A and Yoshizaki T: Bone invasion-targeted chemotherapy with a novel anionic platinum complex (3Pt) for oral squamous cell carcinoma. Cancer Sci 110(10): 3288-3295, 2019. PMID: 31348586. DOI: $10.1111 /$ cas.14145

12 Hoffman RM: Patient-derived orthotopic xenografts: better mimic of metastasis than subcutaneous xenografts. Nat Rev Cancer 15(8): 451-452, 2015. PMID: 26422835. DOI: 10.1038/nrc3972

13 Igarashi K, Kawaguchi K, Murakami T, Kiyuna T, Miyake K, Yamamoto N, Hayashi K, Kimura H, Nelson SD, Dry SM, Li Y, Singh AS, Miwa S, Odani A, Eilber FC, Tsuchiya $\mathrm{H}$ and Hoffman RM: A novel anionic-phosphate-platinum complex effectively targets an undifferentiated pleomorphic sarcoma better than cisplatinum and doxorubicin in a patient-derived orthotopic xenograft (PDOX). Oncotarget 8(38): 63353-63359, 2017. PMID: 28968995. DOI: 10.18632/oncotarget.18806

14 Igarashi K, Kawaguchi K, Li S, Han Q, Tan Y, Murakami T, Kiyuna T, Miyake K, Miyake M, Singh AS, Eckardt MA, Nelson SD, Russell TA, Dry SM, Li Y, Yamamoto N, Hayashi K, Kimura H, Miwa S, Tsuchiya H, Singh SR, Eilber FC and Hoffman RM: Recombinant methioninase in combination with doxorubicin (DOX) overcomes first-line DOX resistance in a patient-derived orthotopic xenograft nude-mouse model of undifferentiated spindle-cell sarcoma. Cancer Lett 417: 168-173, 2018. PMID: 29306021. DOI: 10.1016/j.canlet.2017.12.028

15 Higuchi T, Sugisawa N, Miyake K, Oshiro H, Yamamoto N, Hayashi K, Kimura H, Miwa S, Igarashi K, Kline Z, Bouvet M, Singh SR, Tsuchiya H and Hoffman RM: Pioglitazone, an agonist of PPAR $\gamma$, reverses doxorubicin-resistance in an osteosarcoma patient-derived orthotopic xenograft model by downregulating Pglycoprotein expression. Biomed Pharmacother 118: 109356, 2019. PMID: 31545293 . DOI: 10.1016/j.biopha.2019.109356

16 Higuchi T, Miyake K, Sugisawa N, Oshiro H, Zhang Z, Razmjooei S, Yamamoto N, Hayashi K, Kimura H, Miwa S, Igarashi K, Bouvet M, Singh SR, Tsuchiya $\mathrm{H}$ and Hoffman RM: Olaratumab combined with doxorubicin and ifosfamide overcomes individual doxorubicin and olaratumab resistance of an undifferentiated soft-tissue sarcoma in a PDOX mouse model. Cancer Lett 451: 122-127, 2019. PMID: 30867142. DOI: 10.1016/j.canlet.2019.03.003

17 Zhang Z, Hu K, Kiyuna T, Miyake K, Kawaguchi K, Igarashi K, Nelson SD, Li Y, Singh SR and Hoffman RM: A patient-derived orthotopic xenograft (PDOX) nude-mouse model precisely identifies effective and ineffective therapies for recurrent leiomyosarcoma. Pharmacol Res 142: 169-175, 2009. PMID: 30807865. DOI: 10.1016/j.phrs.2019.02.021

18 Kawaguchi K, Miyake K, Han Q, Li S, Tan Y, Igarashi K, Kiyuna T, Miyake M, Higuchi T, Oshiro H, Zhang Z, Razmjooei S, Wangsiricharoen S, Bouvet M, Singh SR, Unno M and Hoffman RM: Oral recombinant methioninase (o-rMETase) is superior to 
injectable rMETase and overcomes acquired gemcitabine resistance in pancreatic cancer. Cancer Lett 432: 251-259, 2018. PMID: 29928962. DOI: 10.1016/j.canlet.2018.06.016

19 Higuchi T, Sugisawa N, Miyake K, Oshiro H, Yamamoto N, Hayashi K, Kimura H, Miwa S, Igarashi K, Kline Z, Belt P, Chawla SP, Bouvet M, Singh SR, Tsuchiya H and Hoffman RM: Combination treatment with sorafenib and everolimus regresses a doxorubicin-resistant osteosarcoma in a PDOX mouse model. Anticancer Res 39(9): 4781-4786, 2019. PMID: 31519579. DOI: 10.21873/anticanres.13662

20 Igarashi K, Kawaguchi K, Li S, Han Q, Tan Y, Murakami T, Kiyuna T, Miyake K, Miyake M, Singh AS, Eckardt MA, Nelson SD, Russell TA, Dry SM, Li Y, Yamamoto N, Hayashi K, Kimura H, Miwa S, Tsuchiya H, Singh SR, Eilber FC and Hoffman RM: Recombinant methioninase in combination with doxorubicin (DOX) overcomes first-line DOX resistance in a patient-derived orthotopic xenograft nude-mouse model of undifferentiated spindle-cell sarcoma. Cancer Lett 417: 168-173, 2018. PMID: 29306021. DOI: 10.1016/j.canlet.2017.12.028

21 Igarashi K, Kawaguchi K, Kiyuna T, Miyake K, Miyake M, Li S, Han Q, Tan Y, Zhao M, Li Y, Nelson SD, Dry SM, Singh AS, Elliott IA, Russell TA, Eckardt MA, Yamamoto N, Hayashi K, Kimura H, Miwa S, Tsuchiya H, Eilber FC and Hoffman RM: Tumor-targeting Salmonella typhimurium A1-R combined with recombinant methioninase and cisplatinum eradicates an osteosarcoma cisplatinum-resistant lung metastasis in a patient-derived orthotopic xenograft (PDOX) mouse model: decoy, trap and kill chemotherapy moves toward the clinic. Cell Cycle 17: 801-809, 2018. PMID: 29374999. DOI: 10.1080/15384101.2018.1431596

22 Igarashi K, Murakami T, Kawaguchi K, Kiyuna T, Miyake K, Zhang Y, Nelson SD, Dry SM, Li Y, Yanagawa J, Russell TA, Singh AS, Tsuchiya H, Elliott I, Eilber FC and Hoffman RM: A patient-derived orthotopic xenograft (PDOX) mouse model of a cisplatinum-resistant osteosarcoma lung metastasis that was sensitive to temozolomide and trabectedin: implications for precision oncology. Oncotarget 8(37): 62111-62119, 2017. PMID: 28977930. DOI: 10.18632/oncotarget.19095

23 Igarashi K, Kawaguchi K, Kiyuna T, Murakami T, Miwa S, Nelson SD, Dry SM, Li Y, Singh AS, Kimura H, Hayashi K, Yamamoto N, Tsuchiya H, Eilber FC and Hoffman RM: Efficacy in vitro of caffeine and valproic acid on patient-derived undifferentiated pleomorphic sarcoma and rhabdomyosarcoma cell lines. Anticancer Res 37(8): 4081-4084, 2017. PMID: 28739691. DOI: 10.21873 /anticanres.11794
24 Safirstein R, Winston J, Moel D, Dikman S and Guttenplan J: Cisplatin nephrotoxicity: insights into mechanism. Int J Androl 10: 325-346, 1987. PMID: 3583421. DOI: 10.1111/j.13652605.1987.tb00200.x

25 Odani A: Metal complexes and anticancer agents comprising same as active ingredient. Patent WO 2011125911 A1. 2011.

26 Hiroshima Y, Maawy A, Metildi CA, Zhang Y, Uehara F, Miwa S, Yano S, Sato S, Murakami T, Momiyama M, Chishima T, Tanaka K, Bouvet M, Endo I and Hoffman RM: Successful fluorescence-guided surgery on human colon cancer patientderived orthotopic xenograft mouse models using a fluorophoreconjugated anti-CEA antibody and a portable imaging system. J Laparoendosc Adv Surg Tech A 24(4): 241-247, 2014. PMID: 24494971. DOI: 10.1089/lap.2013.0418

27 Kuo TH, Kubota T, Watanabe M, Furukawa T, Teramoto T, Ishibiki K, Kitajima M, Moossa AR, Penman S and Hoffman RM: Liver colonization competence governs colon cancer metastasis. Proc Natl Acad Sci USA 92(26): 12085-12089, 1995. PMID: 8618849. DOI: 10.1073/pnas.92.26.12085

28 Hoffman RM: Orthotopic is orthodox: why are orthotopictransplant metastatic models different from all other models? J Cell Biochem 56(1): 1-3, 1994. PMID: 7806583. DOI: $10.1002 /$ jcb. 240560102

29 Cornillie J, Wozniak A, Li H, Wang Y, Boeckx B, Gebreyohannes YK, Wellens J, Vanleeuw U, Hompes D, Stas M, Sinnaeve F, Wafa H, Lambrechts D, Debiec-Rychter M, Sciot R and Schöffski P: Establishment and characterization of histologically and molecularly stable soft-tissue sarcoma xenograft models for biological studies and preclinical drug testing. Mol Cancer Ther 18(6): 1168-1178, 2019. PMID: 30962320. DOI: 10.1158/1535-7163.MCT-18-1045
Received December 27, 2019

Revised February 19, 2020

Accepted February 20, 2020 